[15] Findik, B. T., Say, R., Unluer, O. B., Demirel, R., Ersoz, A. (2016). Lysozyme Cross-Linked Antibodious Destroyers Against Staphylococcus aureus. Hacettepe Journal of Biology and Chemistry, 44 (4), 477-486.

[16] Bera, A., Herbert, S., Jakob, A., Vollmer, W., Gotz, F. (2005). Why are pathogenic staphylococci so lysozyme resistant? The peptidoglycan O-acetyltransferase OatA is the major determinant for lysozyme resistance of Staphylococcus aureus. Molecular Microbiology, 55 (3), 778-787. doi: 10.1111/j.13652958.2004.04446.x

[17] Kong, C., Chee, C.-F., Richter, K., Thomas, N., Abd. Rahman, N., Nathan, S. (2018). Suppression of Staphylococcus aureus biofilm formation and virulence by a benzimidazole derivative, UM-C162. Scientific Reports, 8 (1). doi: 10.1038/s41598-018-21141-2

[18] Ob unifikatsii mikrobiologicheskih (bakteriologicheskih) metodov issledovaniya, primenyaemih v kliniko-diagnosticheskih laboratoriyah lechebno-profilakticheskih uchrezhdeniy (1985). Ministerstvo zdravookhraneniya SSSR, No. 535. Available at: http://www.alppp.ru/law/zdravoohranenie--fizicheskaja-kultura-i-sport--turizm/zdravoohranenie/64/prikaz-minzdrava-sssr-ot-22-04-1985--535.html

[19] Baron, E. J., Miller, J. M., Weinstein, M. P., Richter, S. S., Gilligan, P. H., Thomson, R. B. et. al. (2013). A Guide to Utilization of the Microbiology Laboratory for Diagnosis of Infectious Diseases: 2013 Recommendations by the Infectious Diseases Society of America (IDSA) and the American Society for Microbiology (ASM)a. Clinical Infectious Diseases, 57 (4), 22-121. doi: 10.1093/cid/cit278

[20] Brilis, V. I., Brilene, T. A., Lentsner, Kh. P., Lentsner, A. A. (1986). Metodika izucheniya adgezivnogo protsessa microorganizmov. Laboratornoe delo, 4, 210-212.

[21] Buharin, O. V., Valyshev, A. V., Elagina, E. E. (2000). Antilizotsimnaya aktivnost anaerobnyh bakteriy fekalnoy mikroflory cheloveka. Zhurnal microbiologii, epidemiologii i immunologii, 5, $20-22$.

[22] Falova, O. E. (2011). Vzaimosvyaz i stepen vurazhennosti adgezivnoy sposobnosti i antilizotsimnoy aktivnosti stafilikokkov, vydelennyh s kozhi ludey, stradaushchih hronicheskimi dermatozami. Vestnik Tomskogo Gosudarstvennogo Universiteta, 349, 188-189.

\title{
CLINICAL-LABORATORY MARKERS OF FIBRILOGENESIS DISORDERS IN THE SEVERITY OF PYELONEPHRITIS IN CHILDREN
}

\author{
Natalia Lukyanenko \\ Department of Clinical Genetics \\ Institute of hereditary pathology of the National Academy of Medical Sciences of Ukraine \\ 31 M. Lysenko str., Lviv, Ukraine, 79000 \\ Department of Propaedeutics of Pediatrics and Medical Genetics \\ Lviv National Medical University, Ukraine, \\ 69 Pekarska str., Lviv, Ukraine, 79010 \\ nslukyanenko@gmail.com \\ Mariana Iskiv \\ Department of Epidemiology congenital and hereditary pathology \\ Institute of hereditary pathology of the National Academy of Medical Sciences of Ukraine \\ 31 M. Lysenko str., Lviv, Ukraine, 79000 \\ iskivmarjana20@gmail.com
}

\footnotetext{
Abstract

Aim of the research: to establish the role of undifferentiated connective tissue dysplasia, as a manifestation of violation of fibrillogenesis, in the severity of the course of pyelonephritis in children.

148 children with pyelonephritis from 3 to 18 years were examined. As a result of catamnestic surveillance, they were divided into 2 groups: I- 92 persons, children with chronic pyelonephritis in which were diagnosed 3 or more episodes of relapse of pyelone-
} 
phritis during the year, and II - 56 children with acute pyelonephritis, in which during the year no relapses were noted. The control group were 65 somatically healthy children of the same age (III - health-control). All children had a routine comprehensive clinical and laboratory examination and clinical and laboratory markers of a fibrillogenic disorder were established.

In children with chronic pyelonephritis, the frequency of all analyzed complaints was significantly higher than in children with acute pyelonephritis without relapses: frequent headaches $-56.52 \%$ versus $25.0 \%$, appetite loss $-28.26 \%$ vs. $19.64 \%$, frequent abdominal pain $-52.17 \%$ vr. $32.14 \%$, increased fatigue $-41.30 \%$ vr. $28.57 \%$.

In children with chronic pyelonephritis, phenotypic signs of undifferentiated connective tissue dysplasia (UCTD) were significantly more marked, such as joint hypermobility (in $52.0 \%$ of children versus $5.4 \%$ ), asthenic body structure (59.0 \% vs. $26.78 \%$ ), visual disturbance ( $84.8 \%$ vs. $32.14 \%$ ), chest deformity (42.4\% vs. $8.9 \%)$, scoliosis (52.17\% vs $10.7 \%)$, arachnodactyly and predisposition to bleeding were observed only in children of the 1st group ( $22.5 \%$ and $4.34 \%$ respectively).

In practically all children with chronic pyelonephritis, the values of free and bound oxyproline fractions in blood plasma were significantly increased $(47.14 \pm 0.03 \mu \mathrm{mol} / 1$ and $40.08 \pm 0.03 \mu \mathrm{mol} / 1$, respectively), according to arithmetic meanings, reliably differing from the data of children with acute pyelonephritis $(17.65 \pm 0.01 \mu \mathrm{mol} / 1$ and $17.22 \pm 0.02 \mu \mathrm{mol} / \mathrm{l})$, in which these oxyproline fractions were elevated only in $12.0 \%$ and $16.0 \%$ of the subjects.

In $97.0 \%$ of children with chronic pyelonephritis, the level of oxyproline in urine was elevated and significantly exceeded the level of excretion of oxyproline in urine in children with acute pyelonephritis.

The presence of UCTD in a child plays an important role in the process of chronic pyelonephritis, and children with its manifestations have a heavier course of disease with frequent relapses, therefore, the presence of signs UCTD is prognostically unsuccessful, which dictates the need for the appointment of metabolic therapy in the first episodes of the disease in children, if they have clinical and laboratory manifestations of UCTD.

Keywords: children, dysplasia of connective tissue, violations of fibrillogenesis, clinical and laboratory markers, oxyproline, pyelonephritis, kidneys.

\section{Introduction}

Diseases of the organs of the urinary system take one of the leading places in the structure of childhood diseases. According to statistics, their prevalence has increased over the years. The frequency of their low-symptomatic atypical prograding is increasing [1].

In recent years, not only in Ukraine, but also in the world, attention is focused on the increase in the frequency of diseases of the organs of the urinary system. At the same time, the structure of nephropathy in children is dominated by diseases of the congenital and hereditary genesis, as well as diseases associated with hereditary predisposition, with a latent onset and torpid flow [2]. Particular attention deserves children with manifestations of connective tissue dysplasia (CTD) [3].

Data from studies conducted in the European post-soviet area show the prevalence of undifferentiated connective tissue dysplasia (UCTD) from $9.0 \%$ to $80.0 \%$, depending on the age, sex, ethnic and clinical groups of the study. At the same time, scientists are concerned about the progressive growth in the population of individuals with a displastic phenotype, which is considered as the result of the impact of new mutagenic factors of social, technological and environmental nature, which form an increase in the so-called "genetic cargo" $[4,5]$. The idea of "syndrome violation of gene homeostasis" were formulated, which may be the result of a mutation of one (monogenic theory), and several (polygenic theory) of genes [6, 7]. The uniqueness of the structure and functions of the connective tissue creates conditions for the emergence of a large number of its anomalies and diseases caused by chromosomal and gene defects that have a certain type of inheritance or arise as a result of external mutagenic effects in the fetal period [8]. In addition to a large number of diseases, most often based on gene defects, birth defects of the connective tissue (CT) of multifactorial nature are often present today $[9,10]$.

CTD are linked both to a violation of the synthesis of collagen and fibrilogenesis, as well as with changes in its biodegradation, fermentopathies, defects of fibronectin, elastin, glycoproteins, proteoglycans, and also with a deficiency of various cofactors of enzymes (magnesium, zinc, copper), ascorbic acid, oxygen and etc., which are involved in the formation of covalent bonds necessary to stabilize collagen structures, which are based on the mutations of genes encoding the synthesis and spatial organization of CT elements $[6,11]$. 
In practice, it is more often encountered with undifferentiated forms of CTD - a genetically heterogeneous group of diseases of multifactorial nature with progressive flow, which are based on the violation of the synthesis, degradation or morphogenesis of the components of the extracellular matrix that occurs during the period of early embryogenesis or postnatal one under the influence of unfavorable environmental factors and can be manifested in different periods of life $[12,13]$.

Kidneys take part in any pathological processes, since they are one of the main organs that support the homeostasis of the body at any age. Clinical manifestations of many diseases in children to a large extent depend on the degree of maturity of urinary organs and urination $[14,15]$.

Taking into account the above remains an open question about the role of dysplasia of connective tissue (DCT) in pyelonephritis in children, the signs of which are increasingly encountered among patients nephrology and significantly affect the nature and course of the disease that causes the occurrence, chronicity and its resistance to therapy.

\section{Aim of the research}

To establish the role of undifferentiated connective tissue dysplasia, as a manifestation of violations of fibrilogenesis, in the severity of the course of pyelonephritis in children.

\section{Materials and methods}

148 children aged 3 to 18 years old underwent inpatient treatment with a diagnosis of pyelonephritis in the I pediatric department of the KZ LOR LODCL "OKHMATDYT" in 2016-2017. According to the results of the observation of patients in the catamnesis of the 1st and 3rd years, they were divided into 2 groups according to the severity of the disease and the frequency of episodes of exacerbation of the inflammatory process of the kidneys: group I (I-CP - 92 persons) children with chronic pyelonephritis, in which there was a more severe course of the disease both in the debut and in the catamnesis, they were diagnosed with 3 or more episodes of pyelonephritis relapse throughout the year, the second group (II-AP - 56 children) who had been diagnosed with acute pyelonephritis, was noticed a mild course of pyelonephritis in the debut of the disease during the year of catamnestic observation no relapse of the disease was noted.

The results of the study of the children of the main groups were compared with the results of a survey of healthy children - 65 somatically healthy children of the same age (III-health-control), which were surveyed during the trips of a group of researchers in ecologically clean areas of Lviv region within the framework of the planned research work. All children were given a comprehensive clinical and laboratory examination in accordance with standard, commonly used in pediatric nephrology and pediatrics by clinical, laboratory and instrumental examinations [16].

When the children received next steps were done:

- a thorough survey of children and their parents by a specially designed questionnaire to specify the necessary anamnestic data;

- clinical examination of children and anthropometric measurements to determine the phenotypic signs of undifferentiated connective tissue dysplasia;

- routine clinical, laboratory parameters (general blood test, general urine analysis, biochemical analysis of blood) and instrumental methods of examination (renal ultrasound, cystic cystography, excretory urography) were determined;

- Brighton and modified criteria of Milkovskaya-Dimitrova and Karkasheva [17] determined the phenotypic signs of undifferentiated connective tissue dysplasia.

- levels of excretion of oxyproline in urine were determined based on the method by E. O. Yuryeva, V. V. Ilgov in modification O. O. Dobryk, S. L. Nyankovsky, M. Yu. Iskiv [1, 18] and free and bound fraction of oxyproline in blood serum using N. P. Sharaeva method [19].

The statistical processing of the research results was carried out using the Microsoft Excel program and the application package Statistica 5.0 for Windows. For the processing of the results that fell under the normal distribution, used the statistical method with the deduction of the arithmetic mean (M), standard deviation (SD). Calculations of the main statistical quantities were carried out according to generally accepted formulas [20]. 


\section{Results of the research}

In children of all observed groups, clinical and paraclinical manifestations of undifferentiated connective tissue dysplasia and violations of fibrillogenesis were investigated.

In children of the I group, complaints of frequent abdominal pain were noted in $52.17 \%$ of cases, while in children of the II group only $32.14 \%$ of the subjects (in control $-7.5 \%$ ). Complaints on frequent headaches were noted in $56.52 \%$ of children in group I, whereas in children of the group II only $25.0 \%$ of children (in control $-4.2 \%$ ). The complaints about fast fatigability were noted in $41.3 \%$ of children in group I, whereas in children of group II fatigue was noted only in $28.57 \%$ of children (in control - 5.6\%). Dysuricular manifestations in children of the I group were noted in $63.04 \%$ of children, while in II group - only in $55.35 \%$ of children (in control - $2.04 \%$ ). In addition, complaints of frequent nosebleeds were noted in $4.34 \%$ of children in group I, which was not observed in children of the II group (in control - $0.02 \%$ ).

In patients of all the observation groups, a history of life was collected, with an emphasis on the study of the frequency of antenatal and postnatal risk factors for the formation of the urinary system pathology and violations of fibrillogenesis (Table 1).

Table 1

The frequency of ante- and postnatal non-specific risk factors for the formation of pathology

\begin{tabular}{|c|c|c|c|c|c|c|}
\hline \multirow{3}{*}{ Non-specific risk factors: } & \multicolumn{6}{|c|}{ Groups of children: } \\
\hline & \multicolumn{2}{|c|}{$\mathrm{I}-\mathrm{CP}, \mathrm{n}=92$} & \multicolumn{2}{|c|}{ II-AP, $n=56$} & \multicolumn{2}{|c|}{ III-health-control, $n=65$} \\
\hline & $\mathbf{n}$ & $\%$ & $\mathbf{n}$ & $\%$ & $\mathbf{n}$ & $\%$ \\
\hline The threat of miscarriage & 17 & $18.48^{*}$ & 9 & $16.07^{*}$ & 6 & 0.09 \\
\hline Gestosis of the first half of pregnancy & 58 & $63.04 * * *$ & 16 & $28.57^{*}$ & 10 & 0.15 \\
\hline Gestosis of the second half of pregnancy & 26 & $28.26^{*}$ & 12 & $21.43^{*}$ & 5 & 0.08 \\
\hline Mother's anemia during pregnancy & 57 & $61.96 * * *$ & 12 & $21.43^{*}$ & 5 & 0.08 \\
\hline Early artificial feeding & 48 & $52.17 * * *$ & 13 & $23.21^{*}$ & 9 & 0.14 \\
\hline Frequent ARD & 56 & $60.87 * * *$ & 17 & $30.36^{*}$ & 8 & 0.12 \\
\hline Atopic diathesis in the past & 8 & $8.7 * * *$ & 5 & $8.93^{*}$ & 1 & 0.02 \\
\hline
\end{tabular}

Note: ${ }^{*}$ - the probable difference between the data of children with pyelonephritis and healthy control group $p<0.01 ; * *-t h e$ probable difference in the indicator between two groups of children with pyelonephritis; $p<0.01$

After children with pyelonephritis came, clinical manifestations and results of ultrasound examination of patients' kidneys were analyzed (Table 2).

Clinical manifestations of general non-specific intoxication were registered in most children of the I group: pallor of the skin was noted in 1.5-2 times more often than in children of the II group (52.0\% vs. $32.0 \%$ of the children in the comparison group), periorbital cyanosis was noted 2 times more frequently in patients of the I group (43.0\% vs. $23.0 \%$ of the children in the comparison group); signs of dysmetabolic nephropathy according to ultrasound data were also diagnosed 2.5 times more often in children of the main group (57.0\% against $20.0 \%$ of children in the comparison group), ultrasound signs of inflammatory process of the kidneys met in $93.0 \%$ of children of both group. Reliable difference in performance of muffled tones of the heart, dental enamel hypoplasia in children of observation group was not noted (Table 2).

In order to study the possible role of undifferentiated connective tissue dysplasia as the causes of the more severe course of pyelonephritis in children and the propensity to chronize the process, as well as in order to predict frequent relapses of pyelonephritis in children, the nature and frequency of phenotypic manifestations of undifferentiated connective tissue dysplasia were analyzed (Table 3).

Table 2

Status of children with pyelonephritis according to clinical and ultrasound examination 


\begin{tabular}{|c|c|c|c|c|}
\hline \multirow{3}{*}{ Clinical manifestations: } & \multicolumn{4}{|c|}{ Groups of children: } \\
\hline & \multicolumn{2}{|c|}{ I-CP, $n=92$} & \multicolumn{2}{|c|}{ II-AP, $\mathbf{n = 5 6}$} \\
\hline & $\mathbf{n}$ & $\mathbf{q}$ & $\mathbf{n}$ & $\mathbf{q}$ \\
\hline Pale skin & 48 & $0.52 *$ & 18 & 0.32 \\
\hline Periorbital cyanosis & 39 & $0.43^{*}$ & 13 & 0.23 \\
\hline Hypertrophy of the tonsils & 37 & 0.40 & 19 & 0.34 \\
\hline Micropolyadenitis & 13 & 0.14 & 9 & 0.16 \\
\hline Hypoplastics of enamel of teeth, I degree & 19 & 0.21 & 12 & 0.21 \\
\hline Hypoplasia of enamel of teeth, II-III degree & 17 & 0.18 & 10 & 0.18 \\
\hline The presence of tooth decay & 31 & 0.34 & 14 & 0.15 \\
\hline The muffled tones of the heart & 14 & 0.15 & 8 & 0.14 \\
\hline Nausea and pain during epigastric palpation & 24 & $0.26^{*}$ & 6 & 0.11 \\
\hline Pain during palpation of the abdomen & 54 & $0.58^{*}$ & 23 & 0.41 \\
\hline Ultrasound signs of dysmetabolic nephropathy & 49 & $0.53^{*}$ & 24 & 0.43 \\
\hline Ultrasound signs of inflammation of the kidneys & 86 & 0.93 & 52 & 0.93 \\
\hline
\end{tabular}

Note: ${ }^{*}$ - the probable difference between the data of two groups of children $p<0.01$

Table 3

The nature and frequency of phenotypic manifestations of the examined children

\begin{tabular}{|c|c|c|c|c|c|c|}
\hline \multirow{3}{*}{$\begin{array}{l}\text { Detected phenotypic manifestations of } \\
\text { UCTD: }\end{array}$} & \multicolumn{6}{|c|}{ Groups of children: } \\
\hline & \multicolumn{2}{|c|}{ I-CP, $n=92$} & \multicolumn{2}{|c|}{ II-AP, $n=56$} & \multicolumn{2}{|c|}{ III-health-control, $n=65$} \\
\hline & $\mathbf{n}$ & $\%$ & $\mathbf{n}$ & $\%$ & $\mathbf{n}$ & $\%$ \\
\hline Hypermobility of the joints & 48 & $52.0^{* *}$ & 3 & 5.4 & 2 & 3.07 \\
\hline Asthenic constitution & 54 & $59.0^{* *}$ & 15 & 26.78 & 8 & 12.3 \\
\hline Vision disorders & 78 & $84.8^{* *}$ & 18 & 32.14 & 5 & 7.69 \\
\hline Arachnodactyly & 21 & $22.8^{* *}$ & - & - & - & - \\
\hline Deformation of the chest & 39 & $42.4^{* *}$ & 5 & 8.9 & 3 & 4.62 \\
\hline Flatfoot & 24 & $26.09^{* *}$ & - & - & - & - \\
\hline Scoliostic posture & 48 & $52.17^{* *}$ & 6 & 10.7 & 3 & 4.62 \\
\hline Tendency to bleeding & 4 & $4.34^{* *}$ & - & - & - & - \\
\hline Emotional lability & 38 & $41.3^{* *}$ & 14 & 25.0 & 9 & 13.85 \\
\hline Umbilical hernia & 9 & $9.78^{* *}$ & 3 & 3.3 & - & - \\
\hline
\end{tabular}

Note: $:^{*}$ the probable difference between the data of children with pyelonephritis and healthy control groups $p<0.01 ; * *-t h e$ probable difference between two groups of children with pyelonephritis $p<0.01$

In order to establish the possible role of undifferentiated dysplasia of connective tissue, as causes of more severe pyelonephritis in children and the propensity to chronize the process, as well as to predict frequent relapses of pyelonephritis in children, all children with pyelonephritis have been evaluated for the levels of oxyproline in plasma and urine as an indicator of increased collagen metabolism and a violation of fibrillogenesis. The obtained data were compared with the data of healthy children in the control group (Table 4).

In order to study the processes of collagen degradation in children of both groups of observation, the level of oxyproline in urine as a measure of collagen metabolism and violation of fibrillogenesis was determined by the method of qualitative reaction (by degree of opacity) for all children. The results of excretion of oxyproline with daily urine in children of both groups of surveillance with pyelonephritis compared with the data of healthy children are presented in Table 5.

Table 4

Indices of collagen collapse in children with pyelonephritis, $(\mathrm{M} \pm \mathrm{m})$ 


\begin{tabular}{|c|c|c|c|c|c|c|}
\hline \multirow{3}{*}{ Indices } & \multicolumn{6}{|c|}{ Groups of children: } \\
\hline & \multicolumn{2}{|c|}{ I-CP, $n=92$} & \multicolumn{2}{|c|}{ II-AP, $n=56$} & \multicolumn{2}{|c|}{ III-health-control, $n=65$} \\
\hline & $\mathbf{M} \pm \mathbf{m}$ & $\mathbf{q}$ & $\mathbf{M} \pm \mathbf{m}$ & $\mathbf{q}$ & $\mathbf{M} \pm \mathbf{m}$ & $\mathbf{q}$ \\
\hline Free oxyproline, $\mu \mathrm{mol} / 1$ & $47.14 \pm 0.03 * * *$ & $0.87 * * *$ & $17.65 \pm 0.01^{*}$ & $0.12^{*}$ & $12.64 \pm 0.38$ & $0.08^{*}$ \\
\hline Bound oxyproline, $\mu \mathrm{mol} / 1$ & $40.08 \pm 0.03 * * *$ & $0.78 * * *$ & $17.22 \pm 0.02 *$ & $0.16^{*}$ & $8.3 \pm 0.29$ & $0.06^{*}$ \\
\hline
\end{tabular}

Note: $:^{*}$ the probable difference between the data of children with pyelonephritis and healthy control groups $p<0.01 ; * *-t h e$ probable difference between two groups of children with pyelonephritis $p<0.01$

Table 5

The content of oxyproline in the urine of children with pyelonephritis

\begin{tabular}{ccccccc}
\hline \multirow{2}{*}{ Indices: } & \multicolumn{3}{c}{ I-CP, $\mathbf{n}=\mathbf{9 2}$} & \multicolumn{2}{c}{ Groups of children: } & \multicolumn{2}{c}{ II-AP, $\mathbf{n = 5 6}$} & \multicolumn{2}{c}{ III-health-control, $\mathbf{n}=\mathbf{6 5}$} \\
& $\mathbf{M} \pm \mathbf{m}$ & $\mathbf{q}$ & $\mathbf{M} \pm \mathbf{m}$ & $\mathbf{q}$ & $\mathbf{M} \pm \mathbf{m}$ & $\mathbf{q}$ \\
\hline $\begin{array}{c}\text { Oxyproline in urine (+), } \\
\text { units of measurement }\end{array}$ & $0.640 .02 \pm$ & $0.97^{*}$ & $0.120 .01 \pm$ & 0.10 & $0.060 .01 \pm$ & 0.08
\end{tabular}

Note: $:^{*}$ the probable difference between the data of children with pyelonephritis and healthy control groups $p<0.01 ; * *-t h e$ probable difference between two groups of children with pyelonephritis $p<0.01$

\section{Discussion}

Comparison of the frequencies of ante- and postnatal non-specific risk factors for the formation of pathology showed that children with chronic pyelonephritis were significantly more likely to be on early artificial feeding in the first year of life (in the I group $52.17 \%$ of children, in the comparison group $-23.21 \%$, in control $-0.14 \%$ ), were more likely to have acute respiratory diseases (in the I group $-60.87 \%$, against $30.36 \%$ of the children in the comparison group, in the control $-0.12 \%)$, the children of both groups were prone to atopy $(8.1 \%$ of children in the It group against $8.93 \%$ of the children in the comparison group, in control $-0.02 \%$ ). Mothers of children of the I group were significantly more likely to have anemia during pregnancy (almost 3 times: $61.96 \%$ vs. $21.43 \%, 0.08 \%$ control) and 2 times more likely to have clinical manifestations of gestosis in the first half of pregnancy ( table 1).

The obtained data allow us to conclude that the frequency of nonspecific ante- and postnatal risk factors for the formation of pathology plays an important role in the formation of nephrological diseases and affects the severity and frequency of relapses of pyelonephritis in the future.

At admission to children of the I group, complaints of frequent abdominal pain were noted in $52.17 \%$ of cases, while in children of the II group only $32.14 \%$ of the subjects (in control $7.5 \%$ ). Complaints on frequent headaches were noted in $56.52 \%$ of children in group I, whereas in children of the group II only $25.0 \%$ (in control - $4.2 \%$ ). Fatigue complaints were noted in $41.3 \%$ of children in group I, whereas in children of group II fatigue was noted only in $28.57 \%$ of children (in control - $5.6 \%$ ). Dysuria in children of the I group was noted in $63.04 \%$ of children, while in II group - only in $55.35 \%$ of children (in control $-2.04 \%$ ). In addition, complaints of frequent nasal haemorrhage were noted in $4.34 \%$ of children in group I, which was not observed in children of the group II (in control $-0.02 \%$ ).

Clinical manifestations of general non-specific intoxication were registered in most children of the I group: pallor of the skin was noted in 1.5-2 times more often than in children of the II group (52.0\% vs. $32.0 \%$ of the children in the comparison group), periorbital cyanosis was noted 2 times more frequently in patients of the I group (43.0\% vs. $23.0 \%$ of the children in the comparison group), signs of dysmetabolic nephropathy according to ultrasound data were also diagnosed 2.5 times more often in children of the main group (57.0\% vs. $20.0 \%$ of children in the comparison group), ultrasound signs of inflammatory renal disease met in $93.0 \%$ of the both group. Reliable difference in performance of muffled heart tones, dental enamel hypoplasia in children of observation groups were not noted (Table 2).

The analysis of the frequency of phenotypic manifestations of UCTD in the examined children indicates that in children of group I phenothylic signs of undifferentiated connective tissue 
dysplasia, such as hypermobility of joints $(52.0 \%$ of children versus $5.4 \%$ in the comparison group, in control - $3.07 \%$ ), asthenic body structure (59.0\% vs. $26.78 \%$, in control - $12.3 \%$ ), visual impairment ( $84.8 \%$ vs. $32.14 \%$, control $7.69 \%$ ), deformation of the chest ( $42.4 \%$ vs. $8.9 \%$, in control $-4.62 \%)$, scoliosis posture $(52.17 \%$ vs. $10.7 \%$, in control $-4.62 \%$ ), arachnodactyly and predisposition to bleeding noticed only in children of the I group ( $22.5 \%$ and $4.34 \%$ respectively, in the control $-0.0 \%$ ), which was not observed in children of the II group. The analysis of phenotypic manifestations of violations of fibrilogenesis points to the role of undifferentiated connective tissue dysplasia, as the causes of the more severe course of pyelonephritis in children and the propensity to chronize the process and predicts frequent relapses of pyelonephritis in children.

According to the literature in older children of the reference group, the level of free and bound oxyproline in the blood plasma is $12.2 \pm 0.49 \mu \mathrm{mol} / 1$ and $8.6 \pm 0.34 \mu \mathrm{mol} / 1$, respectively. The higher the figure, the greater is collagen exchange [5].

In almost all of the examined children of both groups, the rates of increased collagen metabolism were significantly higher than healthy children (Table 4). However, in children of I group, the increased rates of free and bound oxyproline fractions in blood plasma were diagnosed in a larger number of children (78.0\% and $48.0 \%$ respectively), with mean arithmetic data significantly differing from those in the children of the second group (12.0\% and $16.0 \%$ respectively), indicating an increased collagen exchange in children with chronic and frequent relapses of pyelonephritis.

Determination of the level of oxyproline in the urine of children with pyelonephritis testifies to increased decay and excretion of collagen metabolism products in the child's body in $97.0 \%$ of the examined children of the I group, which significantly exceeds the level of excreted oxyproline in the urine in children of the II group (10\%), which indicates a violation of the connective tissue catabolism in virtually all children with chronic pyelonephritis.

Consequently, after analyzing the results of the clinical and paraclinical examination of children with different course of pyelonephritis, one can conclude that undifferentiated connective tissue dysplasia plays an important role in the process of chronic pyelonephritis in children, and children with UCTD manifestations have a more severe course of the disease with frequent relapses, so the presence of signs of UCTD is prognostically unsuccessful, which makes you think over the necessity of appointing nephroprotective and metabolic therapy in the first episodes of the onset of the disease in children in the presence of they have clinical and laboratory manifestations of UCTD.

\section{Conclusions}

1. The presence of nonspecific ante- and postnatal risk factors for the formation of pathology plays an important role in the formation of nephrological pathology in children.

2. In children with chronic pyelonephritis with frequent relapses, the frequency of almost all analyzed complaints was significantly and reliable higher than in children with acute pyelonephritis without relapses: frequent headaches $-56.52 \%$ vs. $25.0 \%$ respectively), appetite loss $28.26 \%$ vs. $19.64 \%$, frequent abdominal pain $-52.17 \%$ versus $32.14 \%$, increased fatigue $41.30 \%$ versus $28.57 \%$.

3. In children with chronic pyelonephritis and inclination to frequent relapse, phenotypic signs of undifferentiated connective dysplasia such as joint hypermobility $(52.0 \%$ of children versus $5.4 \%$ in the comparison group), asthenic body structure of $59.0 \%$ vs. $26.78 \%$ ), visual disturbance ( $84.8 \%$ vs. $32.14 \%$ ), chest deformity ( $42.4 \%$ vs. $8.9 \%$ ), scoliosis posture $(52.17 \%$ vs $10.7 \%$ ), Arachnodactilus and predisposition to bleeding were noted only in children of I group (22.5\% and $4.34 \%$ respectively).

4. In almost all examined children with chronic pyelonephritis, the values of free and bound fractions of oxyproline in blood plasma $(47.14 \pm 0.03 \mu \mathrm{mol} / 1$ and $40.08 \pm 0.03 \mu \mathrm{mol} / 1 \mathrm{respectively})$ were significantly increased, for the mean arithmetic data significantly differ from the data of children with acute pyelonephritis $(17.65 \pm 0.01 \mu \mathrm{mol} / 1$ and $17.22 \pm 0.02 \mu \mathrm{mol} / \mathrm{l})$, in which these oxyproline fractions were elevated only in $12.0 \%$ and $16.0 \%$ examined, respectively, indicating an enhanced collagen exchange in children with chronic pyelonephritis.

5. Determination of the level of oxyproline in urine in children with chronic pyelonephritis testifies to increased decay and excretion of collagen metabolism products in a child's body in 
$97.0 \%$ of the subjects, which significantly exceeds the level of excretion of oxyproline in urine in children with acute pyelonephritis, indicating the expressed disturbance of collagen catabolism in children prone to recurrence of pyelonephritis.

6. The presence of undifferentiated connective tissue dysplasia in the child plays an important role in the process of chronic pyelonephritis, and children with UCTD manifestations have a heavier course of disease with frequent relapses, therefore, the presence of signs of UCTD is prognostically unsuccessful, which dictates the need for appointment of metabolic therapy in the first episodes of the disease in children, if they have clinical and laboratory manifestations of UCTD.

\section{References}

[1] Nyan'kovs'kiy, S. L., Dobrik, O. O., Is'kiv, M. Yu. (2016). Metabolichna terapiya tarol' u kompleksnomu likuvanni displaziy spoluchnoi tkanini u dityachiynefrologiyi. Sovremennay apediatriya, 1 (73), 131-136. doi: 10.15574/sp.2016.73.131

[2] Ivanov, D. D., Korzh, O. M. (2014). Nefrologiya v praktyci simeynogo likarya. Donetsk: Publissher Zaslavsky A. Yu., 464.

[3] Sinitskaya, V. O.,Pavlyshyn, G. A., Chubata, O. B. (2008). Metabolichna terapiya v kompleksnomu likuvanni sindromu displaziyi spoluchnoy tkanini u ditey. ML, 8 (54), 89-90.

[4] Yevtushenko, S. K. (Ed.) (2009). Connective Tissue Dysplasiain Neurologyand Pediatrics (Clinical Picture, Diagnostics, Treatment) Guidelines for physicians. Donetsk: Publisher Zaslavsky A. Yu., 372.

[5] Kadurina, T. I., Gorbunova, V. I. (2009). Displaziya soedinitel'noy tkani. Rukovodstvo dlya vrachey. Sankt-Peterburg: Elbi-SPb, 704.

[6] Solyenko, O. V., Rykalo, N. A., Osypenko, I. P., Soleyko, L. P. (2014). Syndrom nedyferentsiyovanoyi dysplaziyi s poluchnoyi tkanyny: vid kontseptsiyi patohenezu do stratehiyi likuvannya. Vinnytsya: Nova Knyha, 166.

[7] Volovar, O. S. (2013). Fenotypovioznakydysplaziyispoluchnoyitkanyny u patsiyentivizzakhvoryuvannyamy skronevo-nyzhn'oshchelepnoho suhloba. Ukrayins'kyy medychnyy chasopys, 2 (94), 188-192.

[8] Zaremba, E. Kh., Rak, N. O. (2015). Proyavi nediferentsiyovanoi displaziyi spoluchnoi tkanini z boku sertsevo-sudinnoi sistemi u khvorikh na arterial'nugipertenziyu. AML XXI, 2, 14-18.

[9] Kazimirko V. K., Ivanitskaya, L. M., Dubkova A. H., Silant’yeva, T. S. Yvanova, H. P., Poludnenko, M. F. et. al. (2013). Trudnoshchi diahnostyky nedyferentsiyovanoyi dysplaziyi spoluchnoyi tkanyny u praktytsi likarya-revmatoloha. Ukrayins'kiy revmatolohichniy zhurnal, 3 (53), 96-100.

[10] Timochko-Voloshin, R., Mukhin, V. (2014). On the problem of connective tissue dysplasia in children: means of physical rehabilitation. Physical activity health and sport, 1 (15), 46-53.

[11] Nazarenko, L. G. (2010). Dysplasia of connecting work: the role of elimination and gestational problems. Women's Doctor, 1, 42-48.

[12] Kuprienko, N. B., Svetlova, Z. V., Smirnova, N. N. (2017). Metabolic basis of urinary tract infection prophylaxis in children. The Scientific Notes of the I. P. Pavlov St. Petersburg State Medical University, 24 (1), $22-$ 27. doi: HYPERLINK “https://doi.org/10.24884/1607-4181-2017-24-1-22-27” 10.24884/1607-4181-2017-24-1-22-27

[13] Nestorenko, Z. V. (2012). Displaziya soedinitel'noy tkani - mediko-sotsial'niy fenomen XXI veka. Bol'. Sustavy. Pozvonochnik, 1 (5), 17-23.

[14] Povshedna, T. Yu., Shevchuk, D. V., Korniychuk, N. M. (2015). Rol' svoechasnogo likuvannya vrodzhenikh vad rozvitku sechovidil'noy sistemi v poperedzhenni khronichnoy nirkovoy nedostatnosti u ditey. Biologichni doslidzhennya, 423-429.

[15] Lukyanenko, N. S., Kens, K. A., \& Petritsa, N. A. (2016). Evaluating the Diagnostic Value of the Tissue Hypoxia, Membrane Destruction and Undifferentiated Connective Tissue Dysplasia Markers in Young Children with Vesicouretheral Reflux. Child`s health, 6 (74), 86-92. doi: 10.22141/2224-0551.6.74.2016.82138

[16] Nakaz MOZ Ukraini No. 627 vid 03.11.2008 «Pro zatverdzhennya protokolu likuvannya ditey z infektsiyami sechovoi sistemi i tubulointerstitsial'nim nefritom».

[17] Beighton, P., de Paepe, A., Danks, D., Finidori, G., Gedde-Dahl, T., Goodman, R. et. al. (1988). International nosology of heritable disorders of connective tissue, Berlin, 1986. American Journal of Medical Genetics, 29 (3), 581-594. doi:10.1002/ajmg.1320290316

[18] Yur'yeva, E. A., Dlin, V. V. (2002). Diagnosticheskiy spravochnik nefrologa. Moscow. Overley, 12-13. 
[19] Sharaev, P. N. (1981). Metod opredeleniya svobodnogo i svyazannogo oksiprolina v syvorotkekrovi. Laboratornoe delo, 283-285.

[20] Borovikov, V. (2001). Statistica: iskusstvo analiza dannykh na komp'yutere. Dlya professionalov. Sankt-Peterburg: Piter, 656. professionalov. Sankt-Peterburg: Piter, 656.

\title{
EFFICIENCY AND SAFETY OF LEFLUNOMIDE TREATMENT IN PATIENTS WITH PULMONARY SARCOIDOSIS
}

\author{
Volodymyr Gavrysiuk \\ Department of clinical-functional \\ SO "National institute of phthisiology and pulmonology named after F. G. Yanovskyi NAMS of Ukraine" \\ 10 M. Amosova str., Kyiv, Ukraine, 03038 \\ gavrysyuk@ukr.net \\ Ievgeniia Merenkova \\ Department of Clinical and Functional \\ SO "National institute of phthisiology and pulmonology named after F. G. Yanovskyi NAMS of Ukraine" \\ 10 M. Amosova str., Kyiv, Ukraine, 03038 \\ merenkoval@gmail.com
}

Galyna Gumeniuk

Department of Phthisiology and pulmonology

Shupyk National Medical Academy of Postgraduate Education

9 Dorohozhytska str., Kyiv, Ukraine, 04112

gumenuk@ifp.kiev.ua

\begin{abstract}
Patients who have contraindications to the prescription of GCs (glucocorticosteroids), or have developed serious side effects during treatment with GCs, as well as patients with resistance to GCs therapy, are prescribed immunosuppressants.

The aim of the research - to study the efficacy of leflunomide monotherapy in patients with pulmonary sarcoidosis with contraindications to prescription or serious side effects of glucocorticosteroids.

Fourteen patients with sarcoidosis of the respiratory system of stage II were examined - 12 women and 2 men aged 30 to 69 years. In 10 patients there were contraindications to the appointment of GCs (diabetes mellitus - 5, hypertension - 3, obesity - 1, exacerbation of gastric ulcer - 1), which caused the appointment of immunosuppressive therapy as a starting. In 4 cases, serious side effects of SCs were noted, requiring the drug to be abolished (osteoporosis - 3, steroid diabetes -1 ). Leflunomide was administered at a dose of $20 \mathrm{mg}$ per day, daily for 3 months. The evaluation of efficacy was carried out using computed tomography of the thoracic cavity organs, body plethysmography, spirometry and determination of the diffusivity of the lungs.

Monotherapy with leflunomide in patients with contraindications to prescription or serious side effects of GCs was successful in 7 out of 13 patients, in 2 patients there was a stabilization of the process, in 4 patients with leflunomide therapy progression of the disease was noted and in 1 case the treatment was discontinued due to serious side effects of preparation.

The results obtained make it possible to recommend the use of leflunomide as monotherapy in patients with pulmonary sarcoidosis with contraindications to the prescription and/or poor tolerability of GCs and methotrexate. It is necessary to continue studying the possibilities of combined use of leflunomide with other drugs of the first line.
\end{abstract}

Keywords: pulmonary sarcoidosis, treatment of sarcoidosis, leflunomide, side effects.

\section{Introduction}

The main drugs for the treatment of sarcoidosis are glucocorticosteroids, their effectiveness has been proven in several randomized researches [1,2]. Despite the fact that corticosteroids remain the first-line drugs for most patients, cytostatics have been recognized as alternative drugs for the treatment of sarcoidosis. Methotrexate is the most commonly used cytotoxic drug, 